\title{
HOOKE AND WREN AND THE SYSTEM OF THE WORLD: SOME POINTS TOWARDS AN HISTORICAL ACGOUNT
}

\author{
J. A. BenNetT*
}

IT is probably fair to say that our knowledge of the progress made by Robert Hooke and Christopher Wren in explaining planetary motion has been due largely to an interest in the prehistory of Newton's Principia. ${ }^{1}$ Research has often focused on questions arising from the priority dispute between Hooke and Newton and their different contributions are now much better defined. We appreciate more clearly the limitations of Hooke's work. Yet a better understanding of Newton's thinking during the i66os and $167 \mathrm{Os}^{2}$ has served to emphasize the importance of Hooke's clear statement of the problem in his letters of $1679-80$. A planet is continuously deflected from its rectilinear inertial path by a centripetal force varying inversely as the square of its instantaneous distance from the central body: what is the resulting orbit? In this article I shall examine the origin and early development of the ideas of Hooke and Wren and place them within the context of their association together and their discussions with other natural philosophers. Both men were educated within a living scientific tradition: they were helped and encouraged by older men, they collaborated with others in experiments, and they joined in informal discussions in groups. One of the aims of this study is to show how we can see a relation between their explanatory programmes and a background tradition in astronomy and cosmology, a tradition from which Newton was comparatively isolated.

Interest in the origin of Hooke's ideas has led already to the rejection of Newton's claim that Hooke drew on Borelli's explanation of planetary

* 13 Sleaford Street, Cambridge CBI 2 PW.

I want to thank an anonymous referee for some very helpful comments and the President and Council of the Royal Society for permission to quote from manuscripts in thetr possession.

I For studies of Hooke's work, see L. D. Patterson, 'Hooke's gravitational theory and its influence on Newton', Isis, xl (1949), 327-41, and xli (1950), 32-45; J. Lohne, 'Hooke versus Newton', Centaurus, vii (1960), 6-52; A. Koyré, 'An unpublished letter of Robert Hooke to Isaac Newton', Isis, xliii (1952), 312-37, reprinted in Koyré, Newtonian studies (London, 1965), chapter 5 ; A. Koyré, 'Hooke on gravitational attraction', ibid., pp. $180-4$; R. S. Westfall, 'Hooke and the law of universal gravitation', The British journal for the history of science, iii (1967), 245-61 ; F. F. Centore, Robert Hooke's contributions to mechanics (The Hague, 1970), chapter 5. For Wren, see P. D. Lawrence and A. G. Molland, 'David Gregory's Inaugural Lecture at Oxford', Noles and records of the Royal Society of London, xxv (1970), 143-78. Note also A. Koyré, 'La gravitation universelle de Kepler a Newton', Archives internationales d'histoire des sciences, iv (1951), 638-53, and R. S. Westfall, Force in Newton's physics (London, 1971).

2 See D. T. Whiteside, 'Newton's early thoughts on planetary motion: a fresh look', The British journal for the history of science, ii $(1964)$, i $17-37$; 'Before the Principia: the maturing of Newton's thoughts on dynamical astronomy, 1664-1684, Journal for the history of astronomy, $\mathrm{i}$ (1970), 5-19.

THE BRITISH JOURNAL FOR THE HISTORY OF SCIENCE Vol. 8 No. 28 (1975) 
motion 3 and to suggestions that he may have known of the conical pendulum model of Jeremiah Horrox.4 This seems valid as far as it goes, but if we take a wider look at the parallel interests of Hooke's associates, it becomes clear that the question will not be resolved in a single reference. Hooke drew on a more general discussion, which his explicit formulations help us to understand. Further, we can discover the historical circumstances which brought him into this discussion and shaped his particular approach.

\section{Wren and planetary motion}

Throughout the bitter exchanges between Hooke and Newton over priorities and acknowledgements, Wren has left one short statement of his thoughts, and even this is related by someone else. Any study of Wren's natural philosophy is afflicted by a shortage of evidence. It would seem that, forever finding new and more exciting areas of interest, he had little patience for recording and preserving what was already achieved. Much of the record we do have is told at second hand or has been uncovered retrospectively, and his statement about his early thoughts on gravitation emerged in the context of the 1686 dispute between Hooke and Newton, when the point at issue was the origin of the inverse-square : relation between gravitational force and distance.

Hooke's earliest statement of the inverse-square relation occurred in a letter to Newton of January $\mathrm{I}_{79} / 80,5$ but, while his own priority was assured, Newton believed Hooke could not claim even second place behind himself. As he told Halley: 'I am almost confident by circumstances that $\mathrm{Sr}$ Chr. Wren knew ye duplicate proportion wn I gave him a visit, \& then Mr Hook (by his book Cometa written afterward) will prove ye last of us three yt knew it.' 6 This visit had taken place about 1677 ; and during it Wren had 'discoursd of this Problem of Determining the Hevenly motions upon philosophicall principles'.7 Newton asked Halley to investigate: 'You are acquainted wth Sr Christopher. Pray know whence \& whence he first Learnt the decrease of the force in a Duplicate Ratio of the Distance, from the Center.'8 Halley summarized Wren's reply as follows:

3 See A. Armitage, “"Borell's hypothesis" and the rise of celestial mechanics', Annals of science, vi ( 1950$), 268-82$.

4 Ibid., p. 278; Westfall 1967, op. cit. (1), p. 253, note 22; Lawrence and Molland, op. cit. (1), pp. 152-3; Centore, op. cit. (I), pp. 92-4.

5 Hooke to Newton, 6 January $1679 / 80$, in The correspondence of Isaac Newion, ed. H. W. Turnbull (Cambridge, 1960), ii. 309 .

6 Newton to Halley, 20 June I686, ibid., ii. 435. As Koyré has pointed oụt, Newton is indicating that the duplicate proportion is not mentioned in Cometa; see Koyré 1965, op. cit. (1), p. 234 , note 2 .

7 Newton to Halley, 27 May 1686, Correspondence, op. cit. (5), pp. 433-4. It seems fairly certain that, by combining Huygens's expression for centrifugal force, published in 1673 , and Kepler's third law, Wren had derived an inverse-square relation in the restricted case of a circular orbit. Lawrence and Molland, op. cit. (1), pp. 147-54, have collected together the evidence for this and have added the explicit testimony of David Gregory.

Sewton correspondence, op. cit. (5), ii. 434. 
According to your desire in your former, I waited upon $\mathrm{Sr}$ Christopher Wren, to inquire of him, if he had the first notion of the reciprocall duplicate proportion from Mr Hook, his answer was, that he himself very many years since had had his thoughts upon making out the Planets motions by a composition of a Descent towards the sun, \& an imprest motion; but that at length he gave over, not finding the means of doing it. Since which time Mr Hook had frequently told him that he had done it, and attempted to make it out to him, but that he never satisfied him, that his demonstrations were cogent. 9

It would seem that, in reply, Wren leaves aside the more specific question of the precise mathematical relation between gravitational force and distance, but says that the general programme of accounting for a planetary orbit: in terms of central and tangential components was something he had considered himself many years ago and that his frequent discussions with Hooke were subsequent to this.

When Hooke joined the Oxford group about $1655^{10}$ Wren was already an established member, and, while they must have been known to each other from this time (both were helped and encouraged by Seth Ward and John Wilkins), clear evidence of their direct association really begins in the early I66os. Wren had shown an early interest in astronomy and was soon to become involved in its mathematical theory. He was probably introduced to the theories of Kepler by Seth Ward, who wrote in 1654 :

I believe there is not one man here [the University of Oxford], who is so farre Astronomicall, as to be able to calculate an Eclipse, who hath not received the Copernican System, (as it was left by him, or as improved by Kepler, Bullialdus, our own Professor [Ward himself], and others of the Elliptical way)... II

Ward was an important link in the English tradition of Keplerian astronomy, which included men like Thomas Harriot, William Crabtree, Jeremiah Horrox, and Samuel Foster. By 1657 Wren could announce that

... of all the Arguments which the Learned of this inquisitive Age have busy'd themselves with, the Perfection of these two, Dioptricks, and the Elliptical Astronomy, seem most worthy our Enquiry ... ${ }^{\text {I2 }}$

9 Halley to Newton, 29 June 1686 , ibid., ii. $441-2$.

10 'The life of Dr. Robert Hooke', in The posthumous works of Robert Hooke, ed. R. Waller (London, i 705), p. iii.

"S. Ward, Vindiciae academiarum (Oxford, 1654), p. 29. Curiously enough, in the same year Wren assisted John Wallis in observing a solar eclipse at Oxford; see J. Wallis, Eclipsis solaris Oxonii visae anno ... 1654 (Oxford, 1655), p. 2. Walter Pope says that 'The first thing Mr. Ward did, after his Settlement in Oxford [in 1649], was to bring the Astronomy Lectures into Reputation, which had been for a considerable time disused, and wholly left of . . . Besides this, he taught the Mathematics gratis to as many of the University, or Foreigners, as desired that Favour of him'; see W. Pope, Life of Seth Ward (London, 1697), p. 23. Hooke says that around 1655 he had 'an opportunity of acquainting my self with Astronomy by the kindness of Dr. Ward'; see Waller, op. cit. (Io), p. iv.

'2 From the English draft of Wren's inaugural address as Professor of Astronomy at Gresham College, in C. Wren Jnr, Parentalia: or, memoirs of the family of the Wrens (London, 1750), p. 204. 
and he dealt with both these subjects in his subsequent lectures at Gresham College. His Praelectiones Greshamenses in astronomiam Kepleri13 formed part of the continuing English tradition.

We know that by $165^{8}$ Wren had a first-hand knowledge of Kepler's work, since in this year he published a statement of the correct 'area' version of Kepler's second law-more accurate but more difficult to use than the 'equant' version employed by Ward.14 It was appended to Wren's printed solution to a geometrical problem, sent over from France under the pseudonym of Jean de Montfert as a challenge to English mathematicians. ${ }^{15}$ Since Wren thought the problem derived from an equant version of the second law, he felt that a suitable counter-challenge would be 'Kepler's problem', which also concerned the velocity of a planet in an elliptical orbit, as he found it proposed in the Astronomia nova. ${ }^{16}$ As it stood, the area law could not be applied in astronomy, since it yielded no method - for calculating a planet's position at a given time. Kepler had reduced the problem to that of dividing the area of a semicircle in a given ratio by a line through a given point in its diameter. 17 Wren says:

Kepler formerly proposed this type of problem to the most skilled geometers (in his Commentaries on the Motion of Mars, part 4), for indeed Kepler's elliptical hypothesis (that which investigates the equalized anomaly through the areas of the portions of the ellipses analogous: to the mean motion of the planets) is quite spoiled without a solution to this problem. For it then lacks an accurate method by which we can work out a priori the true motion of the planets from their given mean motion. ${ }^{18}$

He goes on to claim: 'We have a geometrical solution of this problem', and Wallis confirms that he had Wren's geometrical solution, using the cycloid, in July $1658.19 \mathrm{He}$ published it the following year. ${ }^{20}$

13 Ibid., p. 239. For references to Wren's lectures on dioptrics, see ibid., p. 24r; The diary and correspondence of Dr. Fohn Worthington, ed. J. Crossley, Chetham Society, xiii (1847), 126-7; The life and works of the Honourable Robert Boyle, ed. T. Birch (2nd edn., London, 1772), vi. I 8 ; T. Birch, The history of the Royal Society of London (London, $1756-7$ ), i. 504 .

14 For this distinction, see J. L. Russell, 'Kepler's laws of planetary motion: 1609-1666', The British journal for the history of science, ii ( 1964$), 17-19$.

's See A. R. Hall, 'Wren's problem', Notes and records of the Royal Society of London, $\mathrm{xx}\left(\mathrm{1}^{6} 6_{5}\right)$, 140-4. The printed solution in the Royal Society's archives is not unique; another is preserved in the Bodleian Library at Aubrey, $x$, ff. $155-6$ (along with printed solutions by Sir Jonas Moore at $\mathrm{ff} .157-6 \mathrm{I}$; for a reference to the printed solution of Thomas Harvie, see J. Collins, The mariners plain scale new plain'd [London, I659], Book II, pp. 50-1). Wren's solution is considered in G. H. Huxley, 'The geometrical work of Sir Christopher Wren', Scripta mathematica, xxv (1960), 203-4.

16 'Since the famous gentleman's problem seems to have regard to the elliptical hypothesis of the planets (for he perhaps has it in mind to make the mean motion of the planets not about the focus of the ellipse but about some other point). Therefore it may be permissible to propose in return by way of extension a problem of the same kind: To divide the Area of a given Semicircle or Ellipse, from any point in any diameter (or the diameter produced) in a given ratio'; Hall, op. cit. (15), p. 143 .

${ }_{7}$ See Russell, op. cit. (14), p. 3.

18 Hall, op. cit. (15), p. 143 .

19 See J. Wallis, Tractatus duo. Prior, de cycloide . . . (Oxford, 1659), p. 70.

20 Ibid., pp. 8o (Ist pagination)- 73 (2nd pagination): 'De problemate Kepleriano per Cycloidem solvendo'. Wren's solution is considered in D. T. Whiteside, 'Wren the mathematician', Notes and records of the Royal Society of London, xv (1960), $108-9$. 
At present this is as far as we can follow Wren's work on the perfection of 'the 'Elliptical Astronomy' as a mathematical account of planetary motion. A complementary tradition in English astronomy, which was also 'Keplerian'; was an interest in physical explanation. F. R. Johnson has shown the' importance of Gilbert's magnetism for English Copernicans in the early seventeenth century. ${ }^{21} \mathrm{He}$ has further shown that this was linked with a 'prevailing eagerness to evolve some new physical explanation of the movements of the planets in their orbits'. ${ }^{22}$ Marke Ridley provided him with a good example of 'the way in which the English scientists were hoping, by a wider application of Gilbert's discoveries and theories, to find a physical explanation of all the planetary motions'. ${ }^{23}$ Wren's inaugural address at Gresham of 1657 reflects this tradition. In a laudatory passage on Gilbert, Wren describes him as 'the Father of the new Philosophy' and, more significantly, as one whom

... I must reverence for giving Occasion to Kepler (as he himself confesses) of introducing Magneticks into the Motions of the Heavens, and consequently of building the elliptical Astronomy. ${ }^{24}$

In the Latin version of this speech, after mentioning Gilbert's work, Wren says:

Hunc sane exosculor, quod ansam Keplero, confitente ipso, dederit magneticos motus in coelum introducendi, unde hypothesis elliptica nata est. 25

These remarks clearly derive from Wren's contemporary study of the Astronomia nova, where the first and second laws appear for the first time and where Kepler's mathematical account is underpinned by physical arguments. The planets are driven round by a quasi-magnetical influence, radiating out from the sun in the form of rays or fibrils and carried round by the sun's rotation. ${ }^{26}$ On the assumption that this influence falls off inversely with distance, a planet's speed will be inversely proportional to its instantaneous distance from the sun, and in the Astronomia nova this relation is incorrectly regarded as equivalent to the area version of the second law.27 From Wren's introduction to his $165^{8}$ solution to Kepler's problem, he was clearly familiar with Kepler's reasoning and aware of the physical basis of his arguments:

21 F. R. Johnson, Astronomical thought in Renaissance England. A study of English scientific writings from 1500 to 1645 (Baltimore, 1937 ), chapter 7.

:2 Ibid., p. 235 .

23 Ibid., p. 237.

24 From the English draft, in Wren Jnr, op. cit. (12), p. 204.

2s J. Ward, Lives of the professors of Gresham College (London, 1740), Appendix, p. 35. I hope to show, in a further paper, that in general Wren's work in astronomy must be seen in the context of an English tradition in the subject.

${ }^{36}$ It is interesting that at a much later date, in September 17 Io, Flamsteed linked the names of Kepler, Wren, and Newton, when he referred to 'Kepler's doctrine of magnetical fibres, improved by Sir Christopher Wren and prosecuted by Sir I. Newton'; see F. Baily, An account of the Rev. John Flamsteed (London, 1835), p. 277.

2 See Russell, op. cit. (14), p. 3. 
Kepler asserted, on physical grounds, that the planets are borne in elliptical orbits about the sun, in such a way that the velocity of the planet is everywhere proportional inversely to its distance from the sun; whence he ingeniously derived the following hypothesis. For let the area of the planetary ellipse be divided by lines drawn from the sun into infinite equal mixtilinear triangles, then the curve of the ellipse will be divided into unequal portions, smaller near aphelion and greater near perihelion; he postulates that the planet will traverse segments in equal times. ${ }^{28}$

Even though our evidence about Wren is meagre, it allows us to say that about $1657-8$ he was studying and trying to advance the Keplerian theory of planetary motion. Also he believed that Kepler had based his account on physical considerations and that Gilbert's work on magnetism had provided a key concept.

Since we have seen that Wren claimed priority over Hooke for the idea that a planet's motion resulted from a combination of central and tangential components, is there anything to suggest that he had taken such a fundamentally important step at this early stage? I want to present two fragments of evidence, which are at least worth considering, and to suggest, tentatively, that they point to one of Wren's sources. First, consider the form of words used in Halley's report of 1686 . Wren had told him that 'he himself very many years since had had his thoughts upon making out the Planets motions by a composition of a Descent towards the sun, \& an imprest motion'. Hooke would have reversed the order and spoken of 'the inflection of a direct motion into a curve'. If it stood alone, this would hardly be very significant, but there is another small piece of evidence.

In the fourth day of Galileo's Discorsi, Salviati discusses the parabolic motion which results from combining two components: a vertical 'naturally accelerated motion' and a horizontal uniform motion. He finds it convenient to express the horizontal component in terms of the vertical height through which a body must fall in order to attain the given speed. At this point Galileo allows Sagredo to interrupt

... in order that I may point out the beautiful agreement between this thought of the Author and the views of Plato concerning the origins of the various uniform speeds with which the heavenly bodies revolve. 29

${ }^{28}$ Quoted from the translation by Hall, op. cit. (15), p. 141. Wren says:

'Asseruit Keplerus, ex causis physicis, planetas ita ferri circa solem in Orbitâ Ellipticâ, ut velocitas planetae sit ubique distantiae ejusdem a Sole reciproce proportionalis; unde sequentem Hypothesin ingeniose commentus est. Secat scilicet aream Ellipseos Planetariae lineis à sole ductis in infinita Triangula Mixtilinae aequalia; unde fit ut Curva Ellipseos dividatur in portiones inaequales, minores quidem circa Aphelium, majores circa Perihelium: per has autem portiones ponit Planetam aequalibus temporibus ferri'; see Wallis, op. cit. (19), p. 80 (1st pagination).

It seems that Wren still believed that these two expressions for the planet's velocity were equivalent in 1677 , since on 20 September Hooke recorded: 'To Sir Chr. Wren . . D Discoursd with him about [lunar] theory. he affirmed that if the motion were reciprocall to the Distance the Degree of velocity should always be as the areas, the curve whatever it will'; The diary of Robert Hooke, $167^{2-1680}$, ed. H. W. Robinson and W. Adams (London, 1935), p. 314 . As is well known, Hooke still accepted the 'inverse distance' law in 1680 .

${ }_{29}$ Galileo, Dialogues concerning two new sciences, trans. H. Crew and A. de Salvio (New York, 1954!, p. 26 I. 
According to the 'Platonic' cosmogony, which Galileo had already described in the Dialogo, God had started all the planets moving from the same point in the universe. From this point each planet had begun to move towards the sun with uniformly accelerated motion, and, when it had reached an ordained speed, God had converted this rectilinear motion into a uniform circular one. $3^{\circ}$ Galileo suggested that calculations based on the known planetary speeds and distances from the sun would confirm the hypothesis.

At the relevant point in Wren's copy of the Discorsi in the Bodleian Library, there is the following note:

Si vera esset hypothesis hac Platonica, oportuit terrā caeterosque planetas centrū aliquid coe[lestem] (solem fortasse) in motu eorū recto respexisse: (sicut gravia nostra ad terrā centrū ferunt ${ }^{\mathrm{r}}$ :) aut alia quaeda assignanda est causa motus accelerati. ${ }^{3}$

It may be translated as follows:

If this Platonic hypothesis was true, the earth and the other planets should have respect to some centre in the sky (perhaps the sun) as regards their straight motion: (just as our heavy bodies are carried towards the centre of the earth) or else some other cause of the accelerated motion is to be assigned.

From their content it seems very likely that the annotations in this volume date from between 1656 and 1660.32 Combined with Wren's interest in the role of 'Magneticks' in celestial physics, this hint from Galileo may have helped him to grasp the fundamental dynamical components of orbital motion-'a composition of a Descent towards the sun, \& an imprest motion'. Implicit in Sagredo's remarks is the Galilean concept of circular

$3^{\circ 0}$ For discussions of Galileo's 'Platonic' cosmogony, see Koyré 1965, op. cit. (1), pp. $201-$ 20; I. B. Cohen, 'Galileo, Newton, and the divine order of the solar system', in Galileo, man of science, ed. E. McMullin (New York, 1967), pp. 207-31 ; S. Drake, 'Galileo's "Platonic" cosmogony and Kepler's Prodromus', Fournal for the history of asironomy, iv (1973), 1 74-91.

${ }^{31}$ Discorsi, e dimostrationi matematichi, p. 193, in Galileo, Opere (Bologna, 1656, 5), vol. ii (Bodleian Library, Savile A. 19). A list of the books donated by Wren to the Savile Library in 1673 is included in my Cambridge University Ph.D. thesis of 1974: 'Studies in the life and work of Sir Christopher Wren'.

${ }^{32}$ The Discorsi is annotated throughout, and the notes do seem to be in Wren's hand, though we have very few examples of his hand during the 1650 . However, compare the MS. 'Anatomia Anguilla fluviatilis' in the Heirloom copy of Parentalia (see Gregg Press reprint, 1965) and note Wren's 1656 reference to 'schemes of several Fishes dissected' in my 'Study of Parentalia', Annals of seience, $\mathrm{xxx}(1973), 147$. Most of the annotations to the Discorsi either indicate the content of, or are complementary to, the text. Some extended notes occur on manuscript pages inserted between pp. 88 and 89 and contain additional explantions and demonstrations, as well as a list of "Authoris principui a Galileo citati'. Six of these extended notes are referred to on the relevant pages of the text (see pp. 57, 89, 96, 103-in this case f. $2^{v}$ of the MS. is mistakenly headed 'Ad problema pag. 10I', I47, 204) and these references attribute the content of the notes to 'D. Ward', i.e. Seth Ward. At p. 96, for example, we find: 'Vide D. Wardi Analysia hujus Problematis max generalius ppositi'. If then these notes were written at a time when Ward was involved in natural philosophy and in direct contact with Wren, they must date from the 1650 . Also, this twovolume edition of works by Galileo (Bodleian Library, Savile A. 18 and 19 ) dates from 1656 . It is interesting that the annotations suggest that some kind of discussion, or perhaps a course conducted by Ward, had centred round the Discorsi; cf. note 11 . In his Gresham speech of 1657 Wren mentioned 'Franciscus Sagredus, one of the Interlocutors in the Dialogues of Gallilaeus'; see Wren Jnr, op. cit. (12), p. 204. 
inertia, but Wren's note, though its meaning is not completely clear, may indicate that he realized that under these circumstances ('Si vera esset hypothesis hac Platonica ...') the 'causa motus accelerati' must continue to operate when God's work of creation was finished. We know that by 166 I Wren had made an experimental study of the laws of impact33 and therefore must have been familiar with part two (and perhaps also part three) of Descartes' Principles of philosophy, containing his analysis of constrained circular motion. We know also that in 166 I (or possibly 1663 ) Huygens discussed with Wren, not only the laws of impact, but also his application of the conical pendulum in clocks and 'all what belongeth to the sayd Invention'.34 That Wren may have benefited greatly from the discussion is clear when we remember that Huygens had composed $D e v i$ centrifuga in 1659 and that some of its demonstrations formed the theoretical basis for this application of the conical pendulum. 35

\section{Hooke and gravitation}

If our knowledge of Wren's first thoughts is uncertain and the evidence to some extent circumstantial, we can date Hooke's ideas more precisely. In his famous programme for a 'System of the world', in the Attempt to prove the motion of the earth ( $6_{74}$ ), while Hooke postulated a gravitational interaction between heavenly bodies, a principle of rectilinear inertia and a decrease of gravitational power with increasing distance, he added: 'what these several degrees are I have not yet experimentally verified'. ${ }^{6}$ Hooke's experiments concerned weighing bodies at different heights above and below the earth's surface, and by 1674 he considered them relevant to an account of celestial mechanics, because the same 'attraction or gravitating power' not only held the parts of heavenly bodies together, but also attracted 'all the other Coelestial Bodies that are within the sphere of their activity'.37 However, there is no suggestion that

33 See below.

34 This emerged from Huygens's priority dispute with Hooke following the publication of Horologium oscillatorium, 1673. At first Huygens was unsure whether he had discussed the matter with Wren during his visit of $166 \mathrm{I}$ or that of 1663 (Oeuvres completes de Christiaan Huygens [The Hague, I888-1950], vii. 314), but he later settled for I66 I (ibid., pp. 337, 391, 43I). The question of which date is correct is not crucial in this context. We know that Wren met Huygens in $166_{3}$, as well as in 1661 ; see B. de Monconys, Journal des voyages (Lyons, 1666), ii. 76-7.

35 See Oeuvres de Huygens, op. cit. (34), xvi. 237-3 I I. Note also ibid., vii. 337, note 13 , and A. E. Bell, Christian Huygens and the development of science in the seventeenth century (London, 1947), pp. $69,120-1$.

${ }^{36} \mathrm{R}$. Hooke, An attempt to prove the motion of the earth from observations... (London, 1674), included in his Lectiones Cutlerianae (London, 1679), which is reprinted in R. T. Gunther, Early science in Oxford (Oxford, 193 I), viii, see pp. 27-8. In the general preface to the Lectiones Cutlerianae Hooke says that this lecture was read at Gresham College in 1670 (and Birch 1756, op. cit. [13], ii. $394,434,447$, confirms that the observations were made in that year), but it is quite possible that the final paragraph at least was added just prior to publication. In 1690 Hooke claimed: 'The Discovery of the Degree of Planetary Gravitation I first Communicated to $\mathrm{S}^{r}$. Christopher Wren about 15 or 16 years Since Sometime before I published my attempt to prove the motion of the Earth ...'; A. R. Hall, 'Two unpublished lectures of Robert Hooke', Isis, xlii (195 I), 225. This may simply be false, or it may be that Hooke and Wren had discussed the possibility of the relation being inverse-square-a possibility which had not yet been verified by Hooke's experiments-and for Hooke this may have been sufficient ground for his later claim.

37 Gunther, op. cit. (36), pp. 27-8. 
his early experiments of $1662-4$ had any implications beyond the parts of the earth.

In his Sylva sylvarum Bacon relates what he says is a well-attested fact: a lump of ore that can be moved by two men at the bottom of a mine, may require at least six men to move it on the surface. From this he observes:

It is a Noble Instance, and is fit to be tried to the full: For it is very probable, that the Motion of Grauity worketh weakly, both farre from the Earth, and also within the Earth: The former, because the Appetite of Union of Dense Bodies with the Earth, in respect of the distance, is more dull; The latter, because the Body hath in part attained his Nature, when it is some Depth in the Earth. $3^{8}$

It is worth noting a relevant citation of this 'Instance' by John Wilkins, who had such an important influence on both Hooke and Wren, as an example of the influence of Gilbert's magnetical theories. In the second edition of his Discovery of a world in the moone (1640) Wilkins argued that in the future a journey to the moon would be possible. 39 Once man had learnt to fly, his weight would not restrict his speed for long, since the earth's gravitational power extended only a finite distance, which Wilkins estimated was about twenty miles. Gravity is not an essential property of matter, but rather 'a respective mutuall desire of union, whereby condensed bodies, when they come within the sphere of their owne vigor, doe naturally apply themselves, one to another by attraction or coition' $.4^{\circ}$ Just as Gilbert held that the magnetic influence of a spherical loadstone is contained within a finite spherical boundary, the orbis virtutis, $4 \mathrm{r}$ the earth's attractive power is contained within a sphere concentric with the earth, and outside this sphere no body will be heavy.42 Gilbert's orbis virtutis is the source of Wilkins' 'sphere of vigor' and of Hooke's 'sphere of activity'. Wilkins cites Bacon's report about moving weights in mines and his inference that 'the nature of gravitie dos worke but weakly also far from the earth' :43

But now you must not conceive, as if the orbe of magneticall vigor, were bounded in an exact superficies, or as if it did equally hold out just to such a determinate line, and no farther. But ... it is probable, that this magneticall vigor dos remit of its degrees proportionally to its distance from the earth, which is the cause of it. 44

However, Wilkins held that this attractive vigour does effectively fall off within a finite, measurable distance.

${ }^{8} \mathrm{~F}$. Bacon, Sylva sylvarum: or a naturall historie in ten centuries . . (2nd edn., London, 1628 ), pp. $11-12$.

$39 \mathrm{~J}$. Wilkins, The discovery of a new world. Or, a discourse tending to prove, that 'tis probable there may be another habitable world in the moone ... (2nd edn., London, 1640), pp. 203-42.

40 Ibid., p. 211.

41 W. Gilbert, De magnete, magneticisque corporibus, et de magno magnete tellure . . (London, $1600)$, pp. $76-7,95-6$, 191.

$4:$ Wilkins, op. cit. (39), pp. $210-20$. For Wilkins, gravity has properties analogous to those of magnetism, but is not magnetical in nature; see ibid., pp. $213-14$.

43 Ibid., p. 216.

44 Ibid., p. 232. 
On 3 December 1662 the Royal Society heard an account of some experiments, made by Henry Power, in which he reported that a weight was measurably lighter at the bottom of a coal mine than at the top.45 $\mathrm{He}$ had discovered this by attaching a thread to one side of a balance, suspending a known weight down a shaft, and observing the weight required to counterpoise it.

On 17 December Hooke, recently appointed the Society's Curator, was asked to perform the experiment 'Of weighing some bodies at the top of Westminster-abbey, and at the foot of it' 4 - an experiment that would test Bacon's inference from the former observation. Hooke, accordingly, applied Power's method above ground and, at the next meeting,

He gave in the following account of the experiment concerning the decrease of gravity, by removing the body farther from the surface of the earth upwards...

'In prosecution of my lord Verulam's experiment concerning the decrease of gravity, the farther a body is removed below the surface of the earth, I made trial, whether any such difference in the weight of bodies could be found by their nearer or farther removal from that surface upwards ...'4i

Hooke goes on to describe experiments made in Westminster Abbey, which revealed no sensible difference. His report shows that his trials had arisen out of a discussion of Power's work and he makes six suggestions for improving Power's experiments, most of them aimed at isolating the different factors influencing the results. He concludes:

These trials, if accurately made, would afford a great help to guess at the cause of this strange phaenomenon. $4^{8}$

The Society did not completely lose interest in the subject 49 and when, in August $166_{4}$, Hooke reported that he was experimenting with a 200-foot pendulum, suspended from the tower of the old cathedral of St Paul's, he was asked to repeat his experiments on weighing bodies at different heights. $5^{\circ}$ Once again he was unable to isolate any effect that could be attributed directly to a variation in gravity. $5 \mathrm{I}$

45 Birch 1756 , op. cit. (13), i. 1 33-4. Note also ibid., pp. 125, 130, and H. Power, Experimental philosophy (London, 1664), p. 177.

${ }_{46}^{6}$ Birch 1 756, op. cit. (13), i. 154 .

4i Ibid., i. $163-4$.

${ }_{4}^{8}$ Ibid., i. 165 .

49 See ibid., i. $234,237$.

50 Ibid., i. $461-2$.

${ }_{51}$ Ibid., i. $466-7$, but see also Hooke's reports, in Works of Boyle, op. cit. (13), vi. 487-93. For later references to Hooke's experiments, see T. Sprat, The history of the Royal Society of London (London, 1667), pp. 224, 227, 247; Waller, op. cit. (10), pp. 182, 563 (with hindsight Hooke could place the experiments in a much wider context). In De potentia restitutiva, in Gunther, op. cit. (36), pp. 337-8, Hooke describes the scales he used at Westminster Abbey and St Paul's and says: 'I propounded the same also to be tried at the bottom and several stations of deep Mines; and D. Power did make some trials to that end, but his Instruments not being good, nothing could be certainly concluded from them.' This may be a useful example of Hooke's attitude in reports of earlier work; his account gives a false impression of the relation between his work and Power's. 
So far the experiments on gravitation had a very limited scope and objective. They derived from an observation of Bacon's and aimed, at most, at 'the cause of this strange phaenomenon'.52 (At this period Hooke suspected that the cause of gravity might be magnetical in nature.53) Also, as far as we can tell, the stimulus came from discussions within the Society and the Society's directives, rather than from Hooke's own interests. However, by 1666 it is clear that the discussion of gravity has taken on a new significance and that Hooke's experiments have become incorporated into a much wider programme. It is valuable, for the moment, simply to follow the record of the Royal Society's minutes.

At the very first meeting following the Society's recess during the Plague, Hooke reported his latest experiments on the variation of gravity. 54 His written paper, submitted at the next meeting, on 2 I March $1665 / 6$, places such experiments in a greatly expanded context:

Gravity, tho' it seems to be one of the most universal active principles in the world, and consequently ought to be the most considerable, yet has it had the ill fate, to have been always, till of late, esteemed otherwise, even to slighting and neglect. But the inquisitiveness of this latter age hath begun to find sufficient arguments to entertain other thoughts of it. Gilbert began to imagine it a magnetical attractive power, inherent in the parts of the terrestrial globe: the noble Verulam also, in part, embraced this opinion; and Kepler (not without good reason) makes it a property inherent in all celestial bodies, sun, stars, planets. This supposition we may afterwards more particularly examine: But first it will be requisite to consider, whether this gravitating or attracting power be inherent in the parts of the earth; and, if so, whether it be magnetical, electrical, or of some other nature distant from either. 55

Hooke's experiments are designed to discover whether gravity is magnetical, since we should then expect to find a variation with distance. His most recent measurements, in 'some considerably deep wells', have revealed no difference in weight and so do not support the magnetical theory. However, he suggests that this is due to the very small differences involved and that a more accurate method, replacing scales and weights by a pendulum clock, should be tried. Results could be compared with measurements of how magnetical attraction decreases with distance. But the cause of gravity is no longer an end in itself; these comparisons may lead us to a model, to be used in answering more significant questions:

... so if this analogy between the decrease of the attraction of the one, and of the gravity of the other, be found real, we may perhaps by the help of the load-stone, as it were, epitomise all the experiments of gravity, and determine, to what distance the gravitating power of the earth acts; and

$5^{2}$ For a contemporary reference to the question of the cause of gravity, see Hooke, Mficrographia (London, 1665), p. 246.

53 See Birch 1 756, op. cit. (13), i. 506-7.

54 Ibid., ii. 65.

55 Ibid., ii. 70. The paper is also printed in Works of Boyle, op. cit. (13), vi. 506-8. 
explicate perhaps divers other phaenomena of nature by ways not yet thought of. 56

During the next weeks Hooke began work on these magnetical experiments.57 However, on 9 May a new impulse was given to the formal discussion at the Royal Society, when

Mr Oldenburg produced a discourse written by Dr. Wallis concerning his hypothesis for solving all the phaenomena of the flux and reflux of the sea, upon the consideration of a common center of gravity of the earth and moon. $5^{8}$

The discourse was read at the following meeting, when it was

... among other things, objected, first, that it appeared not, how two bodies, that have no tie, can have one common center of gravity, upon which the whole hypothesis of Dr. Wallis is founded.59

At the same meeting,

It being mentioned by $\mathrm{Mr}$. Hooke, that the motion of the celestial bodies might be represented by pendulums, it was order'd, that this should be shewed at the next meeting. ${ }^{60}$

So it was that on 23 May 1666 Hooke submitted his well-known paper 'concerning the inflection of a direct motion into a curve by a supervening attractive principle'.6I $\mathrm{He}$ was now explicitly concerned with a physical explanation of planetary motion:

I have often wondered, why the planets should move about the sun according to Copernicus's supposition, being not included in any solid orbs ... nor tied to it, as their center, by any visible strings; and neither depart from it beyond such a degree, nor yet move in a strait line, as all bodies, that have but one single impulse, ought to do.62

The cause favoured by Hooke was the continuous attractive influence of the central body:

For if such a principle be supposed, all the phaenomena of the planets seem possible to be explained by the common principle of mechanic motions; and possibly the prosecuting this speculation may give us a true hypothesis of their motion, and from some few observations, their motions may be so far brought to a certainty, that we may be able to calculate them to the greatest exactness and certainty, that can be desired. ${ }^{63}$

${ }^{6}$ Birch 1756 , op. cit. (13), ii. 72.

57 Ibid., ii. 75. '[Hooke] produced a pair of scales in a box, to make experiments with upon a good loadstone for the finding out of the decrease of its attractive force upon a body, according as it is placed at greater and greater distances, in order to find out, whether gravitation be somewhat magnetical; which he said might be done by comparing the distances of the bodies made use of in the experiments from the superficies of the earth and loadstone with the diameters; it being probable, that if they hold the same proportion, they have the same cause'; ibid., pp. $77-8$ (cf. also pp. $85-6,88$ ).

$5^{8}$ Ibid., ii. 88 .

59 Ibid., ii. 89 .

60 Ibid., ii. 90 .

6r Ibid., ii. 90.

62 Ibid., ii. 91 .

63 Ibid., ii. $9^{1}$. 
Hooke went on to use a conical pendulum to illustrate the effect of a continuous central 'endeavour', producing a variety of elliptical and circular motions according to the tangential velocity given to the bob. The conical pendulum, in spite of its shortcomings as a perfect analogue, thus allowed him to show 'that circular motion is compounded of an endeavour by a direct motion by the tangent, and of another endearour tending to the center'. ${ }^{64}$

The question that most obviously comes to mind has never been seriously attacked. What had happened since August 1664 to elevate Hooke's limited speculations and experiments about gravitation into a programme for a potential system of the world?

\section{Wren and Wallis: the conical pendulum and the common centre of gravity of earth and moon}

Consider first the circumstances in which Hooke produced his paper of May r666. Wallis's explanation of the tides was a developed version of the explanation given in the fourth day of Galileo's Dialogo. Galileo believed that the twofold motion of the earth produced the periodic movement of the waters on its surface. Wallis pointed out that Galileo could not adequately account for all tidal phenomena, but thought that if a third motion were given to the earth-an 'epicyclic' motion about its common centre of gravity with the moon-this would be sufficient to complete the explanation. His primary postulate was that

... the Line of the Annual motion, (whether Circular or Elliptical; of which I am not here to dispute,) will be described, not by the Center of the Earth ... nor by the Center of the Moon . . But by the Common Center of Gravity of the Bodies, Earth and Moon, as one Aggregate. ${ }^{65}$

It was following the reading of this paper at the Royal Society that Hooke 'mentioned ... that the motion of the celestial bodies might be represented by pendulums', 66 and the connexion between Wallis's paper and Hooke's illustration was clearly the idea that it is the common centre of gravity of earth and moon that performs the true elliptical or circular orbit around the sun. After demonstrating the motion of a simple conical pendulum, Hooke attached a smaller pendulum to it

... that it might freely make a circular or elliptical motion round about the bigger, whilst the bigger moved circularly or elliptically about another center. The intention whereof was to explain the manner of the moon's motion about the earth ... ${ }^{67}$

64 Ibid., ii. 92.

65 Wallis's paper and his answers to various objections are printed in Philosophical transactions, , no. 16 (6 August 1666), 263-88; see pp. $272-3$.

66 This was pointed out in A. R. Hall, 'Mechanics and the Royal Society, 1668-70', The British journal for the history of science, iii (1 966-7), 26 .

67 Birch I 756 , op. cit. (13), ii. 92 . 
An elliptical or circular orbit was now described, not by either bob, but by their common centre of gravity:

. . . it appearing evidently thereby, that neither the bigger ball, which represented the earth, nor the less, which represented the moon, were moved in so perfect a circle or ellipsis, as otherwise they would have moved in, if either of them had been suspended and moved singly; but that a certain point, which seemed to be the center of gravity of these two bodies, howsoever posited (considered as one) seemed to be regularly moved in such a circle or ellipsis, the two balls having other peculiar motions in small epicycles about the said point. ${ }^{68}$

The most natural inference from this evidence is not that Wallis's paper stimulated Hooke to devise his pendulum model, but that it prompted him to produce an illustration with which he was already familiar. In his History of the Royal Society Sprat attributed the model to Wren, saying that Wren discovered that a pendulum

... would continue to move either in Circular, or Eliptical Motions ... and that by a complication of several Pendulums depending one upon another, there might be represented motions like the Planetary Helical Motions, or more intricate: And yet that these Pendulums would discover without confusion (as the Planets do) three or four several Motions, acting upon one Body with differing Periods. 69

The History was published in 1667 , although by then Sprat had been working on it for several years. $7^{\circ}$ If his attribution is correct, and most of his catalogue of Wren's work is supported by other evidence, it seems likely that Hooke was drawing on an illustration that had been used by Wren.71 In the priority dispute between Hooke and Huygens, following the publication of Horologium oscillatorium ( 1673 ), Oldenburg wrote to Huygens on 27 June 1673 :

Touchant le pendule circulaire ie le dis encor, tesmoin le Registre de la Soc. Roiale, qu'il y a plusieurs annees, que M. Hook nous en montra icy les proprietez, et mesmes en fit construire des horologes veuës de plusieurs Estrangers. Et M. Wren en auoit desia parlé devant luy à quelques vns de ses amis icy, qui sont prests d'en rendre tesmoignage. $7^{2}$

It is well known that in $163^{8}$ Jeremiah Horrox used the conical pen-

${ }^{68}$ For continued interest in the pendulum model for planetary motion, see ibid., ii. 97, $101,103,105^{-6,} 3^{88,}, 3^{89}$

69 Sprat, op. cit. (5I), pp. $313^{-14}$.

70 Note the edition of Sprat's History by J. I. Cope and H. W. Jones (London, 1966), pp. xiii-xiv, and M. Purver, The Royal Society: concept and creation (London, 1967), pp. 9-15. It may be relevant to note that in Sprat's reply (first published in I665) to Samuel de Sorbière's Voyage into England he mentions that he is working on the History, refers on several occasions to Wren's modesty (as he does in the History), and, noting that Sorbière did not mention Wren in connexion with the King's lunar globe, says: 'Yet I intend to be juster to him'; T. Sprat, Observations on Monsieur de Sorbier's Voyage into England .. . (2nd edn., London, 1668), pp. 4, I I, 253, 151 .

${ }^{7}$ Lawrence and Molland have suggested that Wren may have provided the link between Horrox and Hooke; see Lawrence and Molland, op. cit. (1), pp. 152-3. Another useful article is L. D. Patterson, 'Pendulums of Wren and Hooke', Osiris, $x$ (1952), 277-321.

$7^{2}$ Oeuvres de Huygens, op. cit. (34), vii. 323. 
dulum as a model to illustrate elliptical planetary motion. 73 His explanation involved the attractive force of the sun, though, like Kepler, he required that the planets were pushed around by the sun's rotation.74 Horrox's manuscripts justly caused considerable interest among members of the early Royal Society, 75 and at Oxford in 1664 Wallis began to examine some of them with a view to publication. Wren, who associated fairly closely with both Boyle and Wallis at Oxford during the early 166os, was involved in the first stages of this work. ${ }^{76}$ Though Wallis reported that both he and Wren had perused Horrox's papers before he received the letters from Horrox to Crabtree in August 1664,77 it is quite possible that Wren would have seen these also. As we shall see, at a slightly later date we can link Wallis, Wren, and the very letter which contained the pendulum analogy.

Now we know that Wren had already discussed the conical pendulum with Huygens and, in dynamical terms, had probably advanced beyond Horrox's understanding of its motion. If Wren had seen no more than a general relation between this and planetary motion, both examples of the general problem of motion in a circle, Horrox could indicate that here was a very useful and explicit model, and one which, according to Sprat, Wren developed by substituting for the single pendulum 'a complication of several Pendulums depending one upon another'.

It would seem that Hooke's pendulum model of 1666 owed something to Wallis, Wren, Horrox, and possibly even Huygens. It may also be indirectly related to some rather different experiments on pendulums. The link between Hooke's model and Wallis's paper on tides was the idea that the moon did not simply revolve about the earth, but that both revolved about the common centre of gravity, whose motion in turn described the more simple orbit around the sun. In general terms, the assumption is that if we identify a system of bodies acting upon one another, we can apply the laws of motion to the motion of their common centre of gravity, irrespective of the individual motions and interactions of the bodies. As Wallis put it:

Like as, when a long stick thrown in the Air, whose one end is heavyer than the other, is whirled about, so as that the End, which did first fly foremost, becomes hindmost; the proper line of motion of this whole Body is not that,

i3 See especially Armitage, op. cit. (3), p. 278.

i4 Compare Wallis, in his paper on the tides: 'the Sun by it's motion about it's own Axis, is with good reason judged to be the Physical cause of the Primary Planets moving about it'; op. cit. (65), p. 270 . Wallis had earlier stated a general, non-directional principle of inertia; ibid., p. 268.

75 See Birch 1756 , op. cit. (1 3), i. 386, 395 (it is interesting that Sir Paul Neile, who played an important role in Wren's career as an astronomer, should have had copies of some of Horrox's papers), $4^{12-13}, 414,422,45^{6}, 470,473$; ii. 48 . For the prehistory of Horrox's Opera posthuma, see H. C. Plummer, 'Jeremiah Horrocks and his Opera posthuma', Notes and records of the Royal Society of London, iii (1940), 39-52.

${ }_{76}$ See The correspondence of Henry Oldenburg, ed. A. R. Hall and M. B. Hall (Madison, 1965-), ii. 162-4, 177; Oeuures de Huygens, op. cit. (34), v. 73, 79 . $231-2$.

77 See Birch I 756, op. cit. (13), i. 456; Oldenburg correspondence, op. cit. (76), ii. 209, 213 , 
which is described by either End, but that, which is described by a middle point between them; about which point each end, in whirling, describes an Epicycle. $7^{8}$

Wallis took it for granted that the Copernican system required there to be some physical connexion between the earth and the moon. He was not required to say what kind of connexion this was, but the analogy which readily came to mind was, naturally, a magnetical one:

The Earth and Moon being known to be Bodies of so great connexion (whether by any Magnetick, or whatother Tye, I will not determine; nor need I, as to this purpose;) as that the motion of the one follows that of the other...79

The same was equally true of Jupiter and Saturn and their respective satellites. In reply to the objection that the earth and the moon had no obvious physical connexion, Wallis said

... that it is harder to shew How they have, than That they have it ... How the Earth and Moon are connected; I will not now undertake to shew (nor is it necessary to my purpose;) but, That there is somewhat, that doth connect them, (as much as what connects the Load-stone, and the Iron, which it draws,) is past doubt to those, who allow them to be carryed about by the Sun, as one Aggregate or Body, whose parts keep a respective position to one another. ${ }^{80}$

What was the source of this interest in the motion of the common centre of gravity? Wallis dated it to some time before 1666 . Addressing his paper to Boyle, he spoke of 'that, which at divers times, these three or four years last past, I have been discoursing with your self and others concerning the Common Center of Gravity of the Earth and Moon'. ${ }^{81}$ When we consider the figures who were involved in earlier discussions of the theory of impact, it may not be irrelevant to remember that the principle that the motion of the common centre of gravity is unaffected by interactions between component bodies had already been shown to hold in the case of collisions between bodies.

Wren and his colleague at Gresham College, Lawrence Rooke, had investigated the laws of impact experimentally before Huygens's visit in 166 I, making, as Sir Robert Moray put it, 'diverse experiments with balls of wood \& other stuff hanging by threads' ${ }^{82}$ In April I66I a group of natural philosophers (Moray, Brouncker, Paul Neile, Wallis, Rooke, Wren, and Goddard) met Huygens at his lodgings, and he convinced them of the truth of his theory of impact, which he did not, however, reveal,

$7^{8}$ Wallis, op. cit. (65), p. 288.

79 Ibid., pp. $271-2$.

so Ibid., p. 282.

81 Ibid., p. 264. For an earlier exchange between Wren and Boyle on the Cartesian explanation of tides, see Waller, op. cit. (10), p. vii; Works of Boyle, op. cit. (13), i. 4 I ; Birch 1756 , op. cit. (13), iii. 464 .

${ }_{82}$ Moray to Oldenburg, to October 1665 , Oldenburg correspondence, op. cit. (76), ii. $5^{61}$. 
by successfully predicting the results of some of these experiments. ${ }^{83}$ Apparently prompted by this display, Wren went on to devise a theory of his own, probably in the same year, ${ }^{84}$ and when they were eventually published in 1669 , it was clear that the two theories differed only in formulation. ${ }^{85}$

We have only the 1668 version of Wren's theory of impact (for perfectly elastic bodies), but it must be a good indication of his earlier ideas. ${ }^{86} \mathrm{He}$ begins with the definition:

The proper and most truly natural velocities of bodies are reciprocally proportional to the bodies. ${ }^{87}$

If two bodies move with proper velocities before collision, that is, if their velocities are inversely proportional to their respective bodies (we would say 'masses'), they will rebound with the same speeds as before but in the reverse directions. Wren illustrates this case by reference to a balance in equilibrium, where the weights correspond to the two 'bodies' and their distances from the fulcrum to the respective velocities. With proper velocities, the collision is then 'balanced':

For this reason the collision of bodies having their proper velocities is equivalent to a balance swinging about its centre of gravity. ${ }^{88}$

The ratio of proper velocities is such that, in the model of the balance, the fulcrum coincides with the centre of gravity. In the case of improper velocities, that is, if the velocities before collision are not inversely proportional to the bodies, the fulcrum is displaced to one side of the centre of gravity. The situation after impact will then, according to Wren's theory, be correctly represented by the model if the fulcrum is displaced an equal distance on the other side of the centre of gravity.

83 For Huygens on this, see Oewures, op. cit. (34), vi. 383,386 ; xvi. 204; xxii. 573 ; Oldenburg correspondence, op. cit. (76), v. 126-7; for Moray, see ibid., ii. 561,624 ; Oeuvres de Huygens, vi. 371; for Wallis, see Oldenburg correspondence, v. 193 . Note also Oldenburg at ibid., v. 371-4, 462-5.

24 Huygens said that, while Rooke and Wren had made experiments before April 1661, they had not evolved a theory; see Oeuvres, op. cit. (34), vi. 383,386 . When Wren presented his theory at the Royal Society on 17 December 1668 , he affirmed that he had this hypothesis several years before, when the society began to be formed; and that Mr. Rooke and himself made divers experiments before the society to verify the same: which affirmation of his was seconded and confirmed by several of the members, who were eye-witnesses of those experiments, as the president, Sir Paul Neile, Mr. Balle, and Mr. Hill'; Birch 1 756, op. cit. (13), ii. 335. Cf. ibid., ii. 315,337 ; Oldenburg correspondence, op. cit. (76), v. $117-18,134-5$; Sprat, op. cit. (51), p. 312 . Since the Society was formed in 1660 and Rooke died in 1662 , it seems likely that Wren's theory dates from 166r. Compare Moray in Oeuvres de Huygens, vi. 424 .

85 Wren's original paper is at Royal Society MS. CP. III (I). 43 (with copies at R.B., iv, 29, and Boyle Papers, xx, f. 157). It was printed in Philosophical transactions, iii, no. 43 (1 1 January $1668 / 9), 867-8$, and there is a full translation in Oldenburg correspondence, op. cit. (76), v. $320-1$. The theory is discussed in Hall, op. cit. (66), pp. 30-2, and in Westfall r 971 , op. cit. (1), pp. 203-6.

${ }^{86}$ When Wren received Oldenburg's request, he replied that, having sorted out the relevant papers, 'I found them somwhat indigested as I left them at first. \& I could be glad you would give me a little time to examine them ... I have noe doubt of the truth of the Hypothesis, but of some of the Experiments wch. I would trie over again'; Wren to Oldenburg, 3 November 1668, in Oldenburg correspondence, op. cit. $(76)$, v. 125 . See also note 84 , above.

7 Ibid., v. 320.

"8 Ibid., v. 320. 
Now Wren does not explicitly state that the motion of the common centre of gravity of the two bodies is unaffected by their collision, but it is clear from his formulation that this is the case. As Westfall has pointed out, what Wren is saying is that every impact is dynamically equivalent to an impact with 'proper velocities', and any two bodies approach each other with 'proper velocities' if their collision is viewed from their common centre of gravity. ${ }^{89}$ On Wren's model, the distance from the centre of gravity of the balance to the fulcrum represents the velocity of the common centre of gravity of the bodies. In the case of 'proper velocities', the balance is in equilibrium and the common centre of gravity is stationary.

It is interesting that in the shared interests of Wallis and Wren we find two examples of how an inertial mechanics can be applied to the common centre of gravity of a system of bodies. Although not writing as an historian, it is also interesting that around the turn of the century David Gregory pointed to this connexion:

When a Body revolves about another, the attracting Body it self can't be at rest; but both being acted upon by a mutual Attraction, do revolve about the common Center of Gravity. And if there were more Bodies that mutually attracted one another, they would so move among themselves, that the common Center of Gravity might be either at rest, or in an uniform direct Motion. For it is well known to Geometricians, that the common Center of Gravity does not change its state of Motion or Rest, by reason [of] the action of Bodies upon one another; as has been demonstrated by Mr. Wren and Mr. Hugens. 90

\section{Wren and Hooke: the comets of $166_{4-5}$}

Having seen several relevant elements in contemporary discussion, we can return to Hooke, who, we remember, had made his experiments at St Paul's in August I664. On 5 December 1664 he wrote to Boyle:

We had yesterday in several parts of England, an account of the appearance of a very great comet in the south south-east, with a very long tail, extended towards the north-west; some say about ten yards long, some about two; but how much that is, is difficult to guess, unless we could see it, which I have done all this last night, but to little purpose, by reason of the thickness of the air.9r

This is part of an account of a Royal Society meeting, at which Wren was present. 92 The comet aroused plenty of interest. John Wallis was one of a group of observers at Oxford, who began to look for it on 19 December and saw it first on 23rd.93 The Royal Society were soon receiving observa-

89 Westfall 1971 , op. cit. (I), p. 205.

$90 \mathrm{D}$. Gregory, The elements of astronomy, physical and geometrical (London, 1715) [English translation of Astronomiae physicae et geometricae elementa (Oxford, 1702)], i. 105-6.

${ }_{91}$ Works of Boyle, op. cit. (13), vi. 501. Hooke saw the comet first on 23 December; sec Cometa, in Gunther, op. cit. (36), p. 223, also Birch 1756 , op. cit. (13), i. 51 I.

$9^{2}$ See Works of Boyle, op. cit. (13), vi. 501 , with Birch 1756 , op. cit. (1 3), i. 504-5.

93 See Oldenburg correspondence, op. cit. (76), ii. 339. 
tions and descriptions from various sources, 94 and Hooke was asked to compile a 'history'. 95 The comet was also being observed on the Continent, notably by Huygens and Hevelius, and early in January Adrien Auzout sent over his L'éphéméride du comète ... fait le 2 Janvier 1665.96

During January the Royal Society began to look to Wren for their contribution to the growing debate.97 On 20 January Moray wrote to Huygens :

Nous auons receu de tous costez aussi bien que vous des obseruations de la comete, mais Je ne vous en diray a present si non qu'aussi tost qu'elle aura disparu on vous les communiquera auec les remarques de Monsieur Wren quil les a toutes entre les mains. 98

About the same time (2 I January) Wallis sent his report on the work of Auzout to the Society.99 He pointed out that, while Auzout seemed to think his hypothesis of the rectilinear motion of comets was original, it was 'but that wch others before him have conjectured'. ${ }^{00}$ The theorist who particularly interested Wallis at this time was, of course, Jeremiah Horrox, and he went on to disclose some of Horrox's ideas about comets, 'since conjectures about such Hypotheses be now stirring'. ror Horrox had suggested, in his letters to Crabtree, that a comet is emitted from the sun in a straight line, that its motion is retarded by degrees, and that it is eventually drawn back again into its source. Its path is not completely straight, owing to the effect of the sun's rotation, and he eventually drew the path of the I 577 comet observed by Tycho, as an ellipse which began and ended in the sun. ${ }^{102}$

Now the interests of Wallis and Wren do not appear in isolation. There is evidence of some discussion between them in a manuscript solution by Wallis to a geometrical problem proposed to him early in January by Wren.103 The problem was directly related to the motion of comets. How can a comet's position be found from observations? Hooke tells us that measurements of parallax were associated with difficulties, inaccuracies and disagreements. ${ }^{104}$ If we assume that the comet is moving uniformly in a straight line, the projection of its motion on to the plane of

94 See Birch 1756, op. cit. (13), i. 508, 5 10-1 I; ii. I.

95 Ibid., i. 511 .

${ }_{96}$ Oldenburg correspondence, op. cit. (76), ii. $341-2$.

97 Brouncker also was involved in this. See ibid., ii. 354 ; Birch 1756 , op. cit. (13), ii. I.

g8 Oeuvres de Huygens, op. cit. (34), v. 212.

99 Birch 1756 , op. cit. (13), ii. II, says that the author of the tract in question was Hevelius, but for Hall and Hall on this, see Oldenburg correspondence, op. cit. $(76)$, ii. 356 , note 1 .

roo Ibid., ii. 353.

ror Ibid., ii. 353. Horrox is similarly cited in the paper on tides; see Wallis, op. cit. (65), pp. 280-1.

ro2 See Oldenburg correspondence, op. cit. (76), ii. 353-4; and cf. J. Horrox, Opera posthuma, ed. J. Wallis (London, 1678), pp. $3^{10-11}, 3_{21}$, and Hooke, in Gunther, op. cit. (36), pp. $25^{1-2}$. Wallis and Hooke say that there was no extant explanation by Horrox of the diagram of the I 577 comet.

ro3 Wallis's solution and construction are preserved at Bodleian MS. Don. d. 45, f. $283^{\mathrm{v}}$; it is headed: 'Problema. $D^{r}$ Christopheri Wren, mihi propositur, ist Jan. o. A ${ }_{1}{ }_{1665}$ '.

rot Gunther, op. cit. (36), pp. 236-40. 
the ecliptic will also be uniform and rectilinear. The problem of locating this line in space, given four observations of the comet's longitude, then reduces to the geometrical problem of finding the straight line that is cut by four given straight lines, so that its three portions are related in a given ratio. The ratio is that of the time intervals between the observations. This was the problem that Wren presented to Wallis, and much later, in I677, when Moses Pitt was looking for suitable material to append to a published edition of Horrox's works, Wallis suggested his solution to a problem ' . . . proposed to me by Dr. Wren, to be effected in order to find the distance of comets' ${ }^{105}$

The fact that Wren and Wallis discussed the question of the motion of comets in January I664/5 becomes more significant when we remember Wallis's interest in the ideas of Horrox. One of the letters to which Wallis referred in his report to the Royal Society ${ }^{106}$ was that written to Crabtree on 25 July $163^{8}$. Here Horrox first suggested that comets were emitted from the sun in straight lines, and it was in the same letter that he used the conical pendulum to explain elliptical planetary motion. ${ }^{107}$ Since Wren used the same illustration, the link with Horrox now seems very plausible.

Later in January Wren was again in London ${ }^{108}$ and on $27^{\text {th }}$, Moray wrote to Huygens:

Monsieur le Doctor Wren a entre les mains toutes les obseruations que nous auons euës de toutes parts de la Comete et nous en doibt dire ses pensees bientost. 109

\section{At a Royal Society meeting on I February}

Dr. Wren produced some observations of the comet, with a theory.110

All the evidence goes to show that this 'theory' was Wren's method for locating a comet on the assumption that it moved with uniform rectilinear motion. It included a geometrical construction which was Wren's own solution to the problem he proposed to Wallis (to find the straight line that is divided by four given straight lines in a given ratio) and which Hooke later published in his Cometa.m At the same time Wren also submitted a 'scheme' or diagram of the comet's path, in which he used his

1os Wallis to J. Collins, 22 February $1676 / 7$, in Correspondence of scientific men of the seventeenth century, ed. S. J. Rigaud (Oxford, 1841 ), ii. 605 .

${ }_{106}$ See Oldenburg correspondence, op. cit. (76), ii. $353^{-4}$; Birch I 756, op. cit. (13), ii. I I.

s07 See Horrox, op. cit. (102), pp. 309-14.

${ }^{108}$ In a postscript to his letter of 21 January Wallis asked Oldenburg to present his service to Wren; see Oldenburg correspondence, op. cit. $(76)$, ii. 356 .

109 Oeuvres de Huygens, op. cit. (34), v. 228.

110 Birch 1756 , op. cit. (13), ii. 12. At the same meeting observations of the comet, made by the Earl of Sandwich, 'were referred to Dr. Wren and Mr. Hooke'.

"I Gunther, op. cit. (36), pp. 256-9. On 5 September 1674 Hooke 'Had leave from Sir Ch: to publish his paper about the straight motion of Cometts'; Diary of Hooke, op. cit. (28), p. 120. And again, on 19 May 1676 , Wren'gave me liberty to print his geometricall proposition about 5 lines'; ibid., p. 233. The geometry of Wren's solution has been discussed in Huxley, op. cit. (15), pp. $207-8$. 
construction to locate the comet and describe its motion in a straight line between 20 October 1664 and 20 January $1664 / 5$. We know of this because in April Wren (for reasons I shall discuss shortly) wanted this record returned to him, and Hooke was ordered

... to take a copy of Dr. Wren's scheme of this comet [that of 1664-5], and to return the original to the Doctor for farther consideration. ${ }^{112}$

In his Cometa Hooke gives first Wren's geometrical demonstration, 'as I received it', ${ }^{113}$ and goes on to say:

According to this method I received at the same time, (whilst it yet appeared very visible to the Eye, and was not Retrograde,) the way of the first Comet delineated by the said person [Wren], which did very near solve all the appearances preceding and subsequent, which I have therefore here annexed ... .14

The diagram given by Hooke (see Figure I) corresponds with one of Wren's drawings in the collection at All Souls College, Oxford, which must be the original 'scheme', returned by Hooke in April i 665.115 That the geometrical demonstration and the diagram of the comet's path represent the 'theory' submitted by Wren to the Royal Society in February is confirmed by the fact that Hooke says he had both 'in the beginning of Feb. $1664 / 5$ ' ${ }^{116}$

Using Wren's construction, a comet's path could be determined from four observations, ${ }^{117}$ but only if it was indeed moving uniformly in a straight line. If the same straight line accommodated different sets of observations, it tended to confirm the initial assumption. Now Wren's path for the comet was far from being exactly right, but it seems to have been close enough to lend some support to the hypothesis of rectilinear motion. Hooke says that it 'did very near solve all the appearances preced-

112 Birch 1756 , op. cit. (13), ii. 32.

113 Gunther, op. cit. (36), p. 257.

14 Ibid., p. 258.

115 All Souls Drawings, i. no. 3; published in Wren Society, xii (1935), plate XLVII. Hooke has continued the line of the comet's motion in one of his diagrams (see Figure 1, diagram marked 'Fig. 19') to early February, whereas Wren's last entry was 20 January. Also, in Figs. 19 and 21 he omits the carly section, i.e. 20-31 October 1664 .

${ }_{116}$ See the 'Synopsis', prefixed to Cometa, in Gunther, op. cit. (36), p. 215 . Hooke referred to Wren's method on two later occasions, see Waller, op. cit. (10), p. 104; Philosophical collections, no. 4 (10 January $168 \mathrm{I} / 2$ ), p. 108 .

117 If we look at the diagram (Fig. 1), where Wren has applied his 'theory' to the comet of $1664-5$, in Fig. 19 the semicircle represents the earth's orbit, seen from the south; the continuous line above is the path of the comet, which is moving in the opposite direction to the earth; the dotted line is the projection of this path on to the plane of the ecliptic. Fig. 20 represents observations of the comet's longitude, beginning in November $(N)$. These longitude values are transferred to Fig. 19, where they are represented by lines drawn from the corresponding positions of the earth. The dotted line is then located using four of these longitudelines, given the ratio of the time intervals between the observations. We now have the true distances from the earth to the projections of the comet's positions on to the plane of the ecliptic. These distances are transferred to the line EC in Fig. 21, where $E$ is the earth, and the distances from $E$ to where the latitude values for the comet meet perpendiculars from the corresponding positions on EC, represent the true distances from the earth to the comet. This is what we wanted to find. The perpendiculars can be transferred to Fig. 19, so that we may represent the comet's motion, drawn here on a flat sheet, but in fact inclined to the ecliptic. 


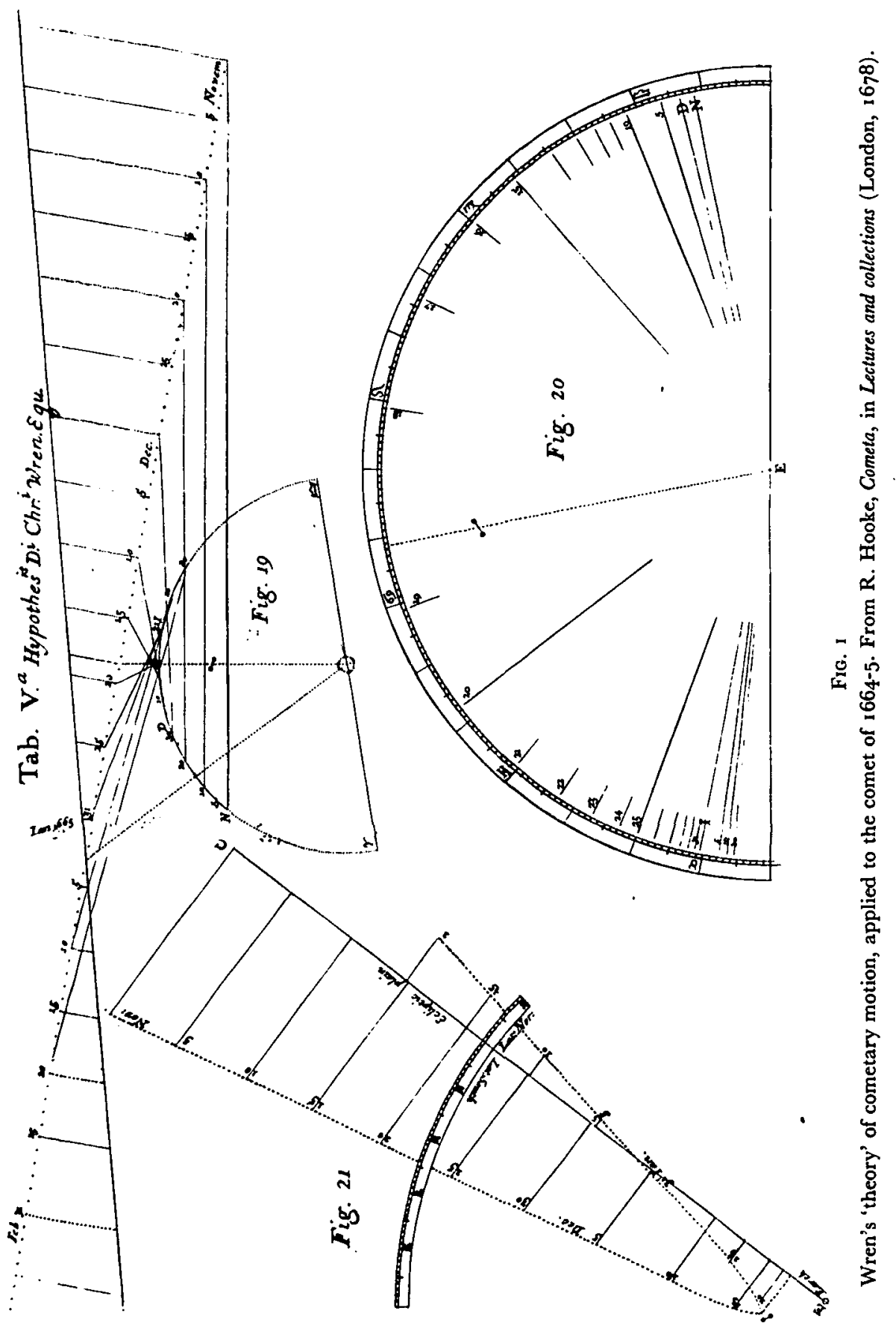


ing and subsequent'. But it seems that Wren was not satisfied. Observations continued to be referred to him ${ }^{118}$ and on 3 February Moray wrote to Huygens:

Je n'en veux rien dire en particulier, que Monsieur Wren n'ait acheué la tasche qu'on luy a imposee, de tirer toutes les conclusions qu'il pourra de toutes les obseruations qu'on luy a mises entre les mains ... .19

On 27 February Moray was still promising Huygens that 'Vous aurez dans peu de temps ce que Monsieur Wren a fait sur la Comete' and he revealed that Wren was intending to publish his results. ${ }^{120}$ Not unusually for Wren, nothing was in fact published.

By late February Hooke was lecturing on the comet at Gresham College. ${ }^{\text {22I }}$ Although he did not eventually leave until early in July, by March Wren was planning his trip to France, and the Society naturally turned once again to Hooke. On I 7 March Moray wrote to Huygens:

On a donné a Monsieur Hook la prouince dont Monsieur Wren ne s'est pas pu descharger a cause d'un voyage qu'il va faire en France. c'est de dresser l'hypothese, et le discours sur la Comete qu'on attend de nostre Societé. ${ }^{122}$

However, in Huygens's reply of $3 \mathrm{I}$ March we find a new factor: he had heard of the appearance of another comet. ${ }^{223}$ Hooke had already told Moray that he had seen the new comet, 124 and Wren probably heard of it from either Moray or Hooke. The fresh possibilities for research immediately reawakened his interest. Wren and Hooke were now both committed to the problem. During the first weeks of April Wren was busy observing the new comet and, as he told Moray in a letter of I I April, he made his first accurate sighting on 7 th. 'Since this I have rose every morning but though the dayes be fair \& the nights, yet the mornings with us are misty toward the Horizon.' 125 It is worth quoting a passage from this letter, since it shows Wren's revived enthusiasm and the physical and theoretical questions raised by the new comet.

... I shall take it for a great Favour, if I may obtain what observations you have at Gresham of this $2^{d}$ comet. Alsoe I would desire of $\mathbf{M}^{\mathrm{r}}$. Hooke he would let me have all the last observations of the last Comet when he began

118 Birch 1756 , op. cit. (13), ii. 12, 13 .

"19 Oeuvres de Huygens, op. cit. (34), v. 235-6. From the information contained in his letters, Moray seems to have been close to Wren's work about this time.

120 Ibid., v. 262. Moray says: '.. Je m'en remets a ce que vous en fera voir ce que Monsieur Wren va publier sur cette matiere.' The catalogue of Wren's works in Wren Jnr, op. cit. (12), p. 240, includes the entries 'De natura $\mathcal{E}$ motibus cometarum' and 'Of the Comet in the Year 1664. N.B. Hypothesis and Theory of Comets; produc'd to the Royal Society. I665'. An early draft for Parentalia, British Museum MS. Add. 25, o7 , f. 91 , also mentions 'Tractatus, De Cometis'.

${ }_{121}$ Pepys records that on I March $1664 / 5$ Hooke delivered 'a second very curious Lecture about the late Comett'; see The diary of Samuel Pepys, ed. R. Latham and W. Matthews (London, I972), vi. 48 .

${ }_{122}$ Oeuvres de Huygens, op. cit. (34), v. 286.

123 Ibid., v. 320.

124 Ibid., v. 322.

22s Wren to Moray, i 1 April [1665], Royal Society MS. EL. W. 3, no. 5 . 
to be stationary or slow in his Motion, \& when \& where he disappeared. I hope my quiet in this place may continue till I have perfected the Hypothesis I began \& made a good essay towardes of the last Comet: \& I have a great desire to find whither this be not yet the same. for who knowes what disposition of the matter makes the various intention or remission of Light in Comets, \& though this last appearance were brighter \& more silver coloured then ever the first was, yet as long as I see it in the same path \& Retrograde when the other should be retrograde, I have some suspicions it may be the same. is it thus, or else doe comets kindle one an other, or propagate by a kind of Generation? but I suspend till I have more observations...

hhis explains why Wren wanted to study again his diagram of the path of the first comet. It was on ig April that Hooke was instructed to make a copy and return the original. The following day Wren wrote to Hooke:

I thanke you for the freedome of your converse wch. I should be glad you would sometimes continue to me whilest I am heer though I dare not importune you to it, for I know you are full of employment for the Society wch. you all-most wholy preserve together by your own constant paines. I have not yet received the Globe \& papers ... I shall be attent to looke for both the Comets if the Sun give us leave, though I am affrayd the 2d. runnes too fast into the South. The Hypothesis of Cassinir26 of the Comets motion about the Dog starre I can by noe meanes approve. I should rather take Lyra for the center then Syrius, though I am not fond of this neither. I have I thinke lighted upon the trew Hypothesis wch. when it is riper \& confirmed by your observations I shall send you. ${ }^{127}$

It is clear from his letters that Wren is not bound by the assumption of uniform rectilinear motion. A further glimpse of the exchanges with Hooke, which Wren refers to, comes from Hooke's reply of 4 May, part of which was printed in Parentalia:

I Hope you received the Globe and Observations which I sent you; you had had them much sooner, but in Truth I could not get the Copy of your Hypothesis, though the Amanuensis was ordered by the Society to have had it ready above a Week before. Those Observations of my own making, I have not yet had Time to adjust so well as I desired . . .128

Hooke expected that in a fortnight's time, when the first comet had passed the sun, he would be able to see both the first comet with a telescope and the second with the naked eye,

... for, if it [the first] continue to move those Ways I have imagined it, whether we take the Supposition of the Motion of the Earth, and imagine the Comet to be moved in a Circle ... or whether we suppose the Earth to

1:6 See Birch 1756, op. cit. (13), ii. 24; Philosophical transactions, i. no. 2 (3 April 1665), 17 ; Oldenburg correspondence, op. cit. (76), ii. $359-67$.

$12 ;$ Wren to Hooke, 20 April [1665], Royal Society MS. EL. W. 3, no. 6.

1:8 Hooke to Wren, 4 May 1665, in Wren Jnr, op. cit. (12), p. 219 ; note Oldenburg correspondence, op. cit. (76), iii. 82-3, 84-5. We know that Hooke was using Wren's double-telescope while making these observations; see Gunther, op. cit. (36), p. 77 , and note also ibid., p. 54, and Waller, op. cit. (10), pp. $498-503$. 
stand still, and the Comet to be moved in a great Circle whose convex Side is turned towards the Earth . . . it must appear again very near the same Place about a Fortnight hence. And I am apt to think the Body of the Comet is of a Constitution that will last much longer than either a Month or a Year, nay than an Age; and if I can be so lucky to meet with it again, I hope to trace it to its second appearing. ${ }^{129}$

Unfortunately at this point Christopher Wren Jnr (editor of Parentalia) omits a section of the letter, so that we know only that Hooke concludes:

But I weary you with my Conjectures; and I doubt not but that before this, you have perfected the Theory of Comets, so as to be able to predict much more certainly what we are to expect of these Comets for the future; whereof if at your Leisure you will please to afford me a Word or two, you will much oblige me...

Although the Royal Society continued to encourage both Hooke and Wren ${ }^{10}$ and Moray later urged that their work should be completed, ${ }^{1}{ }^{3} \mathrm{I}$ there is no further record of Wren's revised solution. What we have seen is that Wren and Hooke freely discussed the problem of the nature and motion of comets and if we look at Hooke's contemporary lectures on the subject, we can see that the questions the comets raised were significant ones.

Hooke's Cometa was published after a comet had appeared in 1677 , but in fact a large section of the work consists of 'my thoughts about those Comets which appeared in 1664 . and 1665 . which I have found in several loose papers of Lectures, read in the beginning of $1665^{\prime} \cdot{ }^{132}$ This section of Cometa seems to be an edited collection of passages drawn together to form a continuous, if not completely consistent, whole. Their sources must range from the lectures of $166_{5}$ to the paper that Hooke eventually produced at a Royal Society meeting on 8 August 1666,133 at a time when the Society was still engaged with the conical pendulum as a model for planetary motion. It therefore covers a very significant period in the development of Hooke's ideas, and we can use internal and external evidence to work out a rough chronology for its parts. A careful study seems to show that at an early date, around March $1664 / 5$, Hooke believed that comets moved in circles and returned periodically (compare his letter to Wren above), but that he later concluded that their paths had straight

129 Wren Jnr., op. cit (12), p. 220.

${ }^{13^{\circ}}$ Note Birch I $75^{6}$, op. cit. (1 3 ), ii. $4^{8}$. As late as 2 I June, at a Royal Society meeting, 'Dr. Wren being desired to leave what he had done about the late comets, promised to do so'; ibid., 59. Wren discussed the comets with Auzout, while he was in Paris (see Oldenburg correspondence, op. cit. [76], iii. $36,3^{8}, 82-3,84-5$ ) and later applied his theory to a comet which appeared in I680; see Birch 1 756 , op. cit. (13), iv. 67 .

${ }_{13 \mathrm{I}}$ Moray to Oldenburg, 28 September ${ }^{66} 5$, Oldenburg correspondence, op. cit. (76), ii. 529 ; note also Wallis at ibid., iii. 342.

${ }_{132}$ Gunther, op. cit. (36), p. 26o. This section covers pp. 223-6o.

133 Birch 1 756, op. cit. (13), ii. I07: 'Mr. Hooke exhibited his observations of the comet in the end of the year $166_{4}$, intimating, that he intended to publish them very shortly.' 
and curved components, related to the gravitational influences of other heavenly bodies. ${ }^{134}$

As we have seen, it was late in April that Hooke became directly associated with Wren's account of the r664 comet and, after describing Wren's theory and its moderate success in this instance, Hooke says:

Now though according to my former Delineation the Comet seemed to take a circuit, as if it would within three years return to its former position, yet I am not wholly convinced that it moves in a circle or Ellipse, but I rather incline to the incomparable Keplers opinion, that its natural motion tends towards a straight line, though in some other suppositions I differ from him.135

Since the natural or, as we should say, inertial motion of a comet 'tends towards a straight line', the rectilinear hypothesis is of some value. But a comet may be drawn from its natural path by the attractive influences of other bodies. In studying Tycho's observations of the 1577 comet, Hooke found that the rectilinear hypothesis was

... the most likely Hypothesis for that Comet, it seeming to solve all the several Phaenomena of the motion and magnitude of the Comet, with the least imaginable difficulty, and to be most agreeable with my physical notions of Comets: For, first it only supposes a solid body moved in a fluid, with an almost direct motion. I say, almost direct, because for some physical reasons, as I have said before, I imagine it not exactly straight, but

134 The fact that different sections are inconsistent with one another is useful in distinguishing between them. A central section (Gunther, op. cit. [36], pp. $241 \mathrm{ff}$.) is definitely of an early date and contains Hooke's conclusion that the first comet is moving in a circle (p. 246). Pepys, loc. cit. (121), records that at Gresham on I March Hooke argued that the first comet had appeared before, in 1618 , and would return at a future date; cf. Gunther, op. cit. (36), p. 243 . Also, on p. 244, Hooke predicts that the first comet will be seen (with a telescope) in a month or six weeks' time, after it has passed the sun. Comparison with Hooke's letter to Wren in Wren Jnr, op. cit. (12), pp. $219-20$, similarly dates this section to March. Note also that Hooke tells Wren that this is so 'whether we take the Supposition of the Motion of the Earth, and imagine the Comet to be moved in a Circle, one Side of which touches, or rather goes within the Orb of the Earth on one Side, and without the Orb of Salurn, or at least that of Jupiter on the other... or whether we suppose the Earth to stand still, and the Comet to be moved in a great Circle whose convex Side is turned towards the Earth', and compare his argument in this section of Comela. Also, on p. 246, Hooke refers to 'this present Comet'. The section before this (Gunther, op. cit. [36], pp. $223 \mathrm{ff}$.) is definitely later and is probably part of the paper of August 1666 . Here the physical discussion is consistent with a comet's path including straight and curved components. Hooke sets himself a number of queries, which he proceeds to answer in turn. This gives the section a certain coherence, in a structure typical of a Royal Society 'history'. It is a survey of a completed piece of work; see ibid., pp. 224, 235, 237. Hooke refers to the results of Hevelius, Gottignies, and Petit (ibid., p. 238) and generally to 'a multitude of other Histories, which I have received concerning that Comet of $64^{\prime}$. For Hooke's connexion with the work of Petit in particular, see Birch 1756, op. cit. (13), ii. 66, 93. Wren had brought Petit's book back from France; see Oldenburg correspondence, op. cit. $(76)$, iii. $4^{8}$. Following what I have called the central section, a slight change is noticeable from p. 247 onwards: Hooke reintroduces physical questions and the comet now seems to be past. The reference to the 'Queries' on p. 247 seems to indicate later insertions. However, the content is still consistent with the central section. There is a more definite change on p. $25^{\circ}$, when Hooke describes how he turned to a study of Tycho's observations of the comet of 1577 . He then makes the very interesting reference to Horrox's hypothesis, with a reproduction of Horrox's diagram of the 1577 comet, presumably that sent to the Royal Society by Wallis; see Oldenburg correspondence, ii. 353 . From p. 250 onwards, the discussion concerns the possible rectilinear motion of comets and its modification by gravitational effects and is consistent with the opening section.

${ }^{3} 35$ Gunther, op. cit. (36), p. 259. 
inflected a little towards the curvity of a circle . . Next, it supposes that body to move in that line almost equal spaces in equal times; I say, almost equal, because some of those equal spaces may be increased by an accelerating cause or principle, such as that of a gravitation towards the body of the Sun' . . . besides, 'tis not unlikely, but that the attraction of the Earth, or some of the other Planets may have some kind of influence on it, especially, when its line of Direction does somewhat nearer approach those attractive points. ${ }^{136}$

(The fact that Hooke discusses the elliptical path which Horrox gave to the comet of $1577^{137}$ emphasizes again the contemporary interest in his ideas and may explain why Hooke turned to a study of this comet. Horrox himself had explained cometary motion as a rectilinear motion modified by the action of the sun, though his account of the sun's action was similar to Kepler's.)

The physical 'notions' and 'reasons' Hooke refers to are firstly that the sun has an attractive influence on the planets, as the planets in turn attract the sun, by analogy with magnetic attractions, and also that 'this attractive virtue may act likewise upon several other bodies that come within the center of its sphere of activity'.138 A comet may at one time have been a gravitating body, like a planet, moving around a central attracting body, but, because of internal changes, it may have lost its gravitating power and been released to move in a straight line, at a tangent to its former path:

... it now leaves that circular way and by its motion (which always tends to a straight line, and would be so were it not bended into a curve by the attractive virtue of the central body) it flies away from its former center by the Tangent line to the last place ... In this line ('tis probable) it passes from one part of the Heavens to another, and so passes through the spheres of the activity of multitudes of central bodies . . .139

Further changes may result in the comet being attracted, or indeed repelled, by these central bodies.

It is clear that through the problem of the motion of comets, Hooke arrived at the idea of combining a rectilinear inertial motion with a central attractive force, and he eventually explained the motion of the 1664 comet in these terms. 140 The comet also drew him into a discussion with Wren, who had already made some progress towards explaining planetary motion and who was now employing the conical pendulum as a model. We have some of their written exchanges on the comets, they had later opportunities for direct discussion, and we know that Hooke witnessed some of Wren's experiments with the conical pendulum. ${ }^{14}$ The two

${ }^{136}$ Ibid., pp. 253-4.

337 Ibid., pp. $25^{1-2}$, and Tab. $1 I^{2}$, Fig. 9.

138 Ibid., p. 228.

139 Ibid., p. 229.

140 Ibid., pp. 254, 259-6o.

${ }_{141}$ Wren was in London in June 1665 . He and Hooke were appointed to a committee to observe the magnetic variation and they discussed 'the art of flying' at a Royal Society meeting on 21 June; when Wren's work on the comets was mentioned; see Birch 1756, op. cit. (13), ii. 54-9. Hooke dated his interest in the conical pendulum to $166_{5}$; see Gunther, op. cit. (36), p. 105. 
men were not only closely associated in the spring of $166_{5}$; but were together again shortly after Wren's return from Paris early in March $1665 / 6.142$

It is worth drawing attention to another of Hooke's associates during this period. After the Plague had forced the Royal Society's adjournment in the summer of 1665 , Hooke spent some time in the country, in Surrey, where he performed experiments in the company of John Wilkins. ${ }^{143}$ Prominent among these were measurements of the weights of bodies suspended in deep wells, intended to test Power's results on the variation of gravity. The fact that Wilkins collaborated with Hooke is particularly interesting when we remember his earlier ideas on the variation of gravity with distance, the analogy with magnetism and the 'sphere of vigor' which extended a finite, measurable distance from the earth. The 'sphere of activity' of a central body was an important part of Hooke's account of the motion of comets. When Hooke reported these experiments, after the Royal Society's recess, he said that his magnetical model for the earth could be used to 'determine, to what distance the gravitating power of the earth acts; and explicate perhaps divers other phaenomena of nature by ways not yet thought of'. ${ }^{144}$

Even though the evidence does not permit a very detailed account, it does seem to show that the period $1664-6$ was crucial in forming Hooke's approach to the problem of planetary motion; that he naturally drew on the ideas of his friends and associates; that he was particularly fortunate in that his study of the comets of $1664-5$ brought him into direct, relevant discussion with Wren; and that his understanding of the dynamics of planetary motion developed out of the problem of the motion of comets. Hooke concluded his discussion of the supposed rectilinear motion of comets of follows:

And particularly by tracing the way of this Comet of 1664 . it is very evident that either the observations are false, or its appearances cannot be solved by that supposition, without supposing the way of it a little incurvated by the attractive power of the Sun, through whose system it was passing, though it were not wholly stayed and circumflected into a Circle . . . 145

The comet was a particularly striking example of 'the inflection of a direct motion into a curve by a supervening attractive principle'. Hooke mentioned in his paper of May 1666 that

${ }_{142}$ See Birch 1756, op. cit. (13), ii. 66, 74; Works of Boyle, op. cit. (13), vi. 5o6. For Wren's return, note Oldenburg correspondence, op. cit. (76), iii. 48 .

${ }^{143}$ See Works of Boyle, op. cit. (13), vi. $501-5$.

144 Birch 1756, op. cit. (13), ii. 72 . Compare Hooke's later ideas in his. 'Discourse on the nature of comets' of 1682 , in Waller, op. cit. (10), pp. 177,178 , and note his reference to the 1664 comet (ibid., p. 168). It is interesting that on 28 September 1665 Moray wrote to Oldenburg: 'I do intend to write within a day or two to Dr Wilkins, to put Mr Hook to the finishing his observations \&c concerning the Cometes ... pray do you solicit the same thing'; Oldenburg correspondence, op. cit. $(76)$, ii. 529 .

245 Gunther, op. cit. (36), p. 260. 
By this hypothesis, the phaenomena of the comets as well as of the planets may be solved . . .146

\section{Conclusion}

The origin of Hooke's explanation of planetary motion is found, not in any single, written source, but in the discussions, collaborations, and shared ideas that were a common feature of natural philosophy in midseventeenth-century England (though by the 166 os the tradition of informal discussion was beginning to decline). Wren had already looked at the problem in physical terms and seems to have advanced some way towards a dynamical explanation of orbital motion. Questions of priority or plagiarism are really beside the point. Hooke simply drew ideas from a discussion, which was probably not confined to those elements we can discover from surviving evidence, and developed them according to his own insights and intuitions. As it happened, his interest in the comets of 1664-5 brought him into collaboration with Wren and this particular problem was important in forging his subsequent understanding of planetary motion.

An important point to notice is that each of the natural philosophers we have mentioned in the context of this discussion-Wallis, Wilkins, Wren, Hooke-had been closely associated with that informal network which was the scientific community of their time. They had joined in groups in Oxford and in London, which in turn derived from earlier associations and circles of like-minded men. They were familiar with that aspect of English natural philosophy which derived from Gilbert, from his interest in magnetism and its role in the cosmos. This is reflected quite clearly in the approach of each of them. They saw no difficulty in thinking in terms of connexions, influences, powers, forces-'whether by any Magnetick, or whatother Tye'-acting between heavenly bodies; forces which could eventually become centripetal forces continuously deflecting a comet or planet from its inertial path. The effect of an exclusively Cartesian or mechanical philosophy, on the other hand, was to concentrate attention on the centrifugal tendency of a body constrained to move in a circle. 147

The sequel is familiar enough. Huygens's formula for centrifugal force, published in 1673 , could be applied to the centripetal force required by Hooke. An inverse-square force law in the restricted case of a circular orbit then became a straightforward deduction from Kepler's third law. While Hooke may have used a less rigorous derivation, ${ }^{148}$ the inverse-

146 Birch 1756 , op. cit. (13), ii. 92.

147 See, for example, Westfall 1971, op. cit. (1), pp. 80-1.

$14^{8}$ See ibid., p. 21 1 ; Westfall 1967, op. cit. (1), p. 259; Lawrence and Molland, op. cit. (1), pp. $15 \mathbf{i}-2$. Huygens sent a copy of Horologium oscillatorium to Wren; see Oeuvres de Huygens, op. cit. (34), vii. 303, 321. Hooke records reading this work on 14 November 1675 and that on the following day he 'Meditated upon motion of Planets of circular pendull'; Diary of Hooke, op. cit. (28), p. 194 . 
square relation gave his programme new possibilities of quantification, which he and Wren tried to pursue in the 1670 and early 1680 . ${ }^{149}$ Hooke eventually supplied Newton with the necessary ingredients for a solution, not asking him to demonstrate that the resulting orbit was an ellipse, but rather to derive the true, and as yet unknown, planetary orbit from first principles. ${ }^{10}$ There is no reason to suppose Hooke was disingenuous when he mentioned to Newton that the solution would be 'of great Concerne to Mankind', not because man would thereby discover the secrets of the universe, but because he could then derive an accurate lunar theory and thence discover the longitude.15r

149 For Hooke's discussions with Wren, see entries for 16 August 1677,20 September ${ }_{1677}$, 18 October 1679,21 October 1679,27 October 1679,8 November 1679 , 26 January $1679 / 80$, at ibid., pp. 307, 314, 427-30, 436; also Newton correspondence, op. cit. (5), ii. $44^{2}$.

150 Ibid., ii. 305, 309, 313 .

isı Ibid., ii. 309. 